\title{
MAN, FATE, AND DEATH IN INDO-EUROPEAN TRADITION ${ }^{1}$
}

\author{
MARTIN LITCHFIELD WEST \\ All Souls College, Oxford
}

\begin{abstract}
RESUMO: Este artigo trata dos conceitos indo-europeus relativos à condição humana, a saber: à natureza do homem, ao papel do destino no planejamento da vida humana, à sina do homem na morte. A argumentação deriva, en parte, de material lingüístico e, em parte, de material literário. O pressuposto é que, assim como a comparação do vocabulário de línguas tão distantes quanto o são o hitita, o sânscrito e o iraniano antigo possibilita a reconstrução de palauras da língua materna, assim também a comparação de motivos paralelos de literaturas tradicionais diferentes poderia revelar idéias e crenças herdadas.
\end{abstract}

PALAVRAS-CHAVE: indo-europeu; homem; destino; morte.

'Indo-European' is primarily a linguistic term. It refers to the great family of languages that now extends across every continent and already two thousand years ago extended across the whole breadth of Europe and considerable parts of central and southern Asia; or it refers to the hypothetical ancestral language from which all the historical Indo-European languages descend. The scientific study of these languages and their relationships began early in the nineteenth century; the terms 'Indo-Germanic' and 'Indo-European' are first recorded in 1810 and 1813 respectively. By the middle of that century some scholars had started to make inferences from the linguistic evidence about the people who spoke the protolanguage: about their habitat, their conceptual world, their social institutions, their mythology. Since 1853 they have succeeded in identifying elements of IndoEuropean poetic language, verbal formulae and stylistic figures. Research on these

1 The material presented in this paper is now incorporated in my book Indo-European Poetry and Myth (Oxford 2007), where all the references may be found. 
matters has continued to the present day. It intensified notably in the second half of the twentieth century, and shows no sign of abating.

I am going to talk about Indo-European concepts concerning the human condition: the nature of man, the role of fate in shaping his life, his destiny in death. The evidence is partly drawn from linguistic material, partly from literary. The assumption is that, just as comparison of vocabulary in widely separated languages such as Hittite, Sanskrit, and Old Irish makes it possible to reconstruct words of the parent language, so comparison of parallel motifs in different traditional literatures may show up inherited ideas and beliefs. Of course it is a game to be played with caution. We must discount material that might have spread from one literature to another by diffusion. For example, if we find parallels between Greek and Latin idiom or ideology, in most cases they will be due to the influence of Greek culture on Rome, not to common inheritance from Indo-European. We must also be aware of subgroupings among the Indo-European languages. Just as in reconstructing a manuscript archetype one cannot simply take agreements between any two or three manuscripts as reflecting the archetype reading, but must consider their stemmatic relationships, and the degree to which these relationships are confused by cross-contamination, so with Indo-European. There is now wide agreement among linguists that the Anatolian branch, represented by Hittite and related languages of Asia Minor, was the first to diverge from common Indo-European, which continued to evolve for a considerable period after the split before breaking up further. Within the non-Anatolian body, one can identify an eastern family represented by Indo-Iranian, Armenian, Phrygian, and Greek, and a looser western group, within which Italic and Celtic are seen as having a closer relationship. Scholars often light on parallels between the oldest Greek and Indian texts, between Homer and the Rigveda, and claim that they reflect Indo-European heritage. In fact, in the absence of supporting evidence from the west, such parallels are evidence only for a late phase of east Indo-European, which can be called 'Graeco-Aryan'. If the parallels extend from India to Ireland or Iceland, we may be justified in arguing to a higher level of Indo-European, 'Level 2'. Only if they are shared by Anatolian too can we claim to be getting back to Level 1, the level of the common parent language - and then only if later contacts between Anatolia and the other relevant traditions are excluded as an explanation.

With these principles in mind, let us turn to the business in hand.

A pervasive feature of Indo-European thought and language was the representation of totalities in terms of polar dualities: heaven and earth, creatures two-footed and four-footed, powers seen and unseen. Mankind was seen as forming 
a duality with the gods. In Indian, Iranian, Greek, Celtic, and Old Norse texts we meet various expressions meaning 'gods and men' or 'gods and mortals'. They are treated as two separate races or breeds. The Rigveda speaks often of the jána or ján(i)man of the gods, or of gods and mortals, just as in Greek epic we have $\theta \varepsilon \hat{\omega} v$

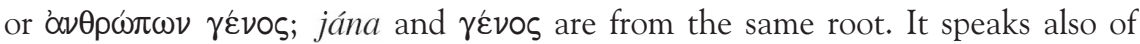
'both races', jánasī ubhṛ, meaning gods and men. In Old Saxon and Old English we have the phrase 'men's kin', equivalent to modern English 'mankind', and parallel to 'giants' kin'. Kind and kin are etymologically cognate with révos and jána.

Many branches of the Indo-European family - Indo-Iranian, Phrygian, Illyrian, Baltic, Germanic, Celtic, Italic - share a term for 'gods' reconstructed as *deiwós, which meant literally 'heavenly ones'; that is to say, they belonged in the sky. (Anatolian has a related form.) Men are defined by contrast as the terrestrial ones. The word for 'human being' in many languages is derived from the basic Indo-European word for the earth, * $d^{h} e^{\prime} \hat{g}^{h}$ om- $/ d^{h} \hat{g}^{h} m$-: Latin humus 'earth', homo 'man'; old Lithuanian žmuõ, pl. žmónès; Phrygian zemelos; from proto-Celtic *gdon-yo-, Old Irish duine, Welsh dyn, Breton den; from proto-Germanic *guman, Gothic and Old English guma, Old Norse gumi, Old High German gomo. The idea

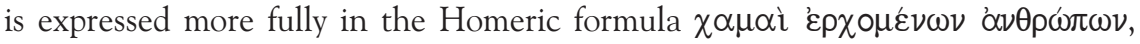
'men who go upon the earth', in a similar phrase in one of the Eddic poems, and in the Lithuanian żmõgus 'human being', literally 'earth-goer', an old compound incorporating the same roots as Greek $\chi \alpha \mu \alpha^{\prime}$ ind $\beta \alpha^{\prime} i v \omega$.

In several traditions we find the opposition of gods and men, divine and human, still expressed in words from the old Indo-European roots for 'heaven' and 'earth'. In a Vedic hymn the god Rudra is said to have concern both for the earthly race and for the heavenly one, kșámyasya jánmanas ... divyásya. In the Phrygian inscriptions there is much use of the formula $\mu \varepsilon \delta \varepsilon \omega \varsigma \kappa \varepsilon \zeta \varepsilon \mu \varepsilon \lambda \omega \varsigma \kappa \varepsilon$ and variants, understood to mean 'among both gods and men'. A Gaulish boundary stone of the second or first century $\mathrm{BC}$ designates a piece of land with the remarkable compound adjective TEUOXTONION, rendered in the Latin version of the inscription as co $(m)$ munem deis et hominibus. In Old Irish the derivative of *gdonyo- had lost its inital velar and come to alliterate with the word for 'god', and so in early texts we find for doine domnaib scéo déib 'over worlds of men and (over) gods'; sech bid día, bid duine 'he will be both god and man'; arddu deeib dóen 'a man more exalted than the gods'. And in an early Welsh poem: as clywo a duw a dyn, 'let both God and man hear it'. In Greek the old Indo-European words for gods and men have been replaced by others, but we still find the traditional antithesis between heavenly gods and terrestrial humans, as in the Odyssey (6.150/3), when Odysseus says to 
Nausicaa, 'If you are one of the gods who dwell in the broad heaven, I reckon you are most like Artemis ... but if you are of the mortals who live on earth, then thrice fortunate are your parents and brothers.'

In the east Indo-European or Graeco-Aryan area we also find an alternative antithesis, by which gods and men are contrasted as immortals and mortals. In the Rigveda, as in Homer, the gods are sometimes called 'the immortal gods', or simply 'the immortals', and in Latin too, perhaps under Greek influence, we have the phrase di immortales, or immortales alone, contrasted with mortal men as in Naevius' famous epitaph, immortales mortales si foret fas flere. We also find in the oldest Indian and Iranian poetry a crossing of the two antitheses, with the result that 'gods and men' is expressed by the phrase 'celestials and mortals' rather than 'celestials and terrestrials' or 'immortals and mortals'. In Armenian, original IndoEuropean *mrto- 'mortal' has developed into the ordinary word for 'man', mard.

The Indo-Europeans probably had no consistent doctrine about the origin of humankind. We find the reflexes of several different conceptions. One is that we are the children of Mother Earth. Earth has the title of Mother in most branches of Indo-European tradition: Anatolian, Indic, Greek, Baltic, Slavic, Germanic, Celtic. That she is specifically our mother is explicit in Indic, Greek, Baltic, Germanic, and Celtic. Inseparable from this is the notion that the Sky-god, IndoEuropean *Dyéus, is our father. Scholars have long noted the correspondence of Sanskrit Dyáuș pitâ, Greek Zzùs $\pi \alpha \tau \eta ি p$, Illyrian Deipaturos, Latin Iuppiter and Diespiter, Umbrian Iupater, and there are Anatolian equivalents with a different word for 'father': Hittite attaš Šiuš, Luvian tatiš Tiwaz, Palaic Tiyaz ... papaz. In the Rigveda and Atharvaveda he is coupled directly with Earth the Mother:

Díyaus pítah, Pŕthivi mâtar ádhrug,

O Heaven (our) father, Earth (our) guileless mother.

They are parents of the gods, and indeed parents of all, just as Zeus in Homer is $\pi \alpha \tau \dot{\eta} \rho \dot{\alpha} \nu \delta \rho \hat{\omega} \nu \tau \varepsilon \theta \varepsilon \hat{\omega} \nu \tau \varepsilon$, 'father of gods and men'. An echo of this ancient theory of humankind's parentage survives in an Old English prayer where Earth, the mother of men, is said to be made pregnant in God's embrace; the Christian God here takes the place of the divinized Heaven.

How is our birth from Earth to be imagined? We may think of the various Greek and Germanic myths according to which men, or a particular ancestor of men, grew up from the earth in tree form. Trees and other plants do, after all, grow out of the earth when it has been fertilized by the rain from heaven. In the old German poetic genealogy reported by Tacitus, a divine figure called Tuisto grew 
out of the earth and became the father of Mannus, the ancestor of all the Germans. Mannus is a form of the common Germanic word for 'man'. The same root exists in Sanskrit: mánu-s means a man, or mankind, and it is also the name of the divine progenitor of mankind, or at least of the Aryans. This coincidence of Indic and Germanic myth indicates that Manus the ancestor of humankind goes back to Indo-European myth, at any rate to Level 2, the post-Anatolian phase.

The parallels go further than that. The Germanic Mannus' father has the name Tuisto, which is thought to mean 'twin' or 'hermaphrodite'. If he was bisexual and able to fertilize himself, there was no need to look elsewhere for a mother for Mannus. Another figure called 'Twin', Yama or Yima, plays a role in Indo-Iranian myth as the first mortal man or the first king. He is the son of the solar deity Vivasvat or Vīvahvant. Some accounts give him a sister, also called Twin (Yamī, Yimeh), with whom he has incest, or at least she pleads with him to do so. We can guess that originally the myth featured not a pair but a single bisexual creature capable of procreation by himself. Such a figure appears later in a more philosophical Iranian cosmogony, where he is identified with Time.

In Icelandic myth too we find a primeval figure with a name that seems to be from the same root meaning 'twin'. This is the giant Ymir, formed from the action of the southern heat on the northern ice. The first man and woman came from his sweat; but it is also said that one of his legs begot a son with the other, which looks like a half-forgotten or bowdlerized paraphrase of procreation by selffertilization.

The story goes on that Ymir was afterwards killed and dissected, and the world was made out of his body: the heaven from his skull, the earth from his flesh, the mountains from his bones, the trees from his hair, the sea and rivers from his blood. The Iranian Yima, after a blessed reign on earth, lost his majesty and was cut in two, though there is no record of what became of the halves. In India it is not Yama but another primal man who suffers an analogous fate: this is Purusha $\hat{u}$ púruṣa is another word meaning 'man' - who according to a famous Vedic hymn was sacrificed by the gods, and the cosmos was made out of him, the heaven from his head, the air from his navel, the earth from his legs, and so forth.

In this mythical complex there seems to be an amalgamation of two separate concepts: (1) the primal bisexual 'Twin' who generates the first humans, and (2) the primal giant who is cut to pieces to make the parts of the world. It is not obvious why the same figure should play both roles, as both the Nordic Ymir and the Iranian Yima seem to do. If we are descended from a being who first begot our 
ancestors and then was divided to make heaven and earth, we cannot also be descended from Mother Earth. We could imagine a link between them if the bisexual being, rather than giving birth to men and women, had been divided in two, a male half and a female half, like the primeval double creatures portrayed by Aristophanes in Plato's Symposium. If these ideas do go back to Indo-European antiquity, they may have been current separately rather than in combination.

Let us go back to the basic notion that we are descended from Father Sky and Mother Earth. It implies that there could be a celestial as well as a terrestrial element in our nature. But clearly we walk on the earth and not in the sky, and this is the basis of the opposition between *deiwós and ${ }^{*} \hat{g}^{h} d^{h}$ ómyōs. We have to be

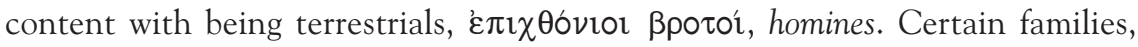
however, do claim an individual infusion of heavenly genes. In Greece, at Rome, in India, and among the Germanic peoples we hear of particular kings and heroes who were the sons of gods. The British Royal Family has a genealogy which leads back ultimately to the god Woden. There is no reason why such claims should not go back to Indo-European times. People did not, I suppose, go around saying 'I am the son of a god', but 'my family (or my tribe) originally sprang from a god'.

Anyone can see that human lives differ widely in length and fortune. For the most part the distribution of longevity and prosperity appears to be arbitrary; in other words, governed by divine agency. The Indo-Europeans seem to have believed that it was predetermined, not by a universal, all-encompassing Destiny that laid things down at the beginning of time, but by supernatural females attending the birth of each child and establishing the contours of its life then and there as it lay in its cradle. I do not know of any Indo-Iranian evidence for this idea, but it is found all over Europe, as well as in Bronze Age Anatolia. The names of the goddesses are different in different countries, but this is understandable. When deities are especially dangerous, it is common to avoid the name that is most truly theirs and to replace it with some substitute; we often find alternative names current at the same time. The important thing is the unity of the conception over such a large part of the Indo-European area, which makes it likely that it goes back to Level 1 Indo-European.

In the Odyssey Alcinous says that once Odysseus has been brought home to Ithaca, he will experience whatever Aisa and the Spinners (K $\lambda \hat{\omega} \theta \varepsilon \varsigma$ or $\mathrm{K} \alpha \tau \alpha \kappa \lambda \hat{\omega} \theta \varepsilon \varsigma)$ spun for him with their flax at his birth. In the Iliad the same expression is used with Aisa or Moira as the subject: both words mean 'share, portion', and the goddess is at the same time the personification of what is allotted 
to one in life and the agent that allots it. Hesiod registers a trio of Moirai, 'who give mortal men both good and ill'. One of them is called the Spinner, K $\lambda \omega \theta \omega$. The three Moirai play a prominent role in modern Greek folk tales, or did in the 19 th century. They come on the third night after a child's birth and pronounce its destiny.

At Rome the corresponding divinities are called the Parcae. The name may suggest 'the Sparing Ones', but that does not give an obvious sense, and Varro may have been nearer the mark when he explained it as related to pario 'give birth'; it may be contracted from *Paricae. Their name then marks them as goddesses who attend at a birth. Their individual names are given as Nona, Decuma, and Morta, which pretty clearly express the blunt doctrine that the child is born in the ninth month or the tenth, or it is born dead. Morta, however, may have had a wider reference. Livius Andronicus used her name in translating a verse of the Odyssey. The Homeric line 'when the dread $\mu$ oip $\alpha$ of death strikes a man down' became in Livius' version 'when the day arrives that Morta has proclaimed', quando dies adueniet quem profata Morta est. Morta appears here as the power that predetermines the date of an individual's death by declaring it. Another Latin name for the Fates, Fata, expresses the same idea of destiny being fixed by pronouncement.

The Parcae, like the Greek Moirai, spin threads of fate. Everyone who has read Catullus' poem 64 remembers the refrain from their song at the wedding of Peleus and Thetis: currite ducentes subtegmina, currite fusi, 'run on, spindles, drawing out the threads for the weft'. It is possible that Catullus and other Latin writers took over the spinning image from Greek literature, and that it does not reflect native tradition. But the Latin evidence is not crucial to the argument, as we find the motif in various parts of barbarian Europe, not just in literature but in folk belief, in circumstances where its presence is unlikely to be due to classical influence.

In Nordic mythology the relevant figures are the Nornir or Norns, a name of unclear etymology. They appear as goddesses who attend the birth of children and shape their lives. When Helgi the slayer of Hunding was born in Brálund,

Night fell on the homestead, the Norns came, they who shaped his life for the prince; they ruled the prince should be most famous, and that he'd be held the best of warriors. They twisted strongly the strands of fate as castles crashed in Brálund; 
they separated the golden threads

and fastened them in the moon's mid hall [that is, in the sky].

The ends are fastened east and west, meaning that Helgi's power will extend over the whole land. Similarly in another poem it is said that the threads of Sigurd's fate lie about every land.

The power of fate is especially manifest on the battlefield, where some fall prey to death and others survive. In Homeric language the Moira of Death is said to come and stand by the warrior as he falls. The poet of the pseudo-Hesiodic Shield of Heracles more graphically describes the Kêres, personifications of fated death, as horrible female figures present on the field and struggling to seize men as they fought, and then he or an interpolator has thrown in the names that belong to the Moirai, Klotho, Lachesis, and Atropos. In Norse mythology it is properly the Valkyries who have the task of choosing which warriors are to die and go to Valhalla. But the distinction between Norns and Valkyries becomes blurred, so that the Valkyries too can be portrayed as spinning or weaving men's destinies.

The Norns also appear as three goddesses of fate who sit by the well of Urð at the foot of the cosmic tree Yggdrasill. Urð corresponds to a word for fate found also in Old Saxon and Old English: wurth or wyrd. In Old English, Wyrd is a power that weaves destinies. A poem in the Exeter Book (an important corpus of AngloSaxon poetry) uses the expression 'Wyrd wove that for me', and in another a man's fated death is 'woven on Wyrd's loom'. Later the Wyrds appear as a group, as in Chaucer, 'the Werdys that we clepyn (call) Destiné', and most famously as the Weird Sisters in Shakespeare's Macbeth.

The word has a significant etymology. It is related to German werden, 'become', 'come about'. But in Latin the same verb means 'to turn', vertere; and in Sanskrit the middle form vártate has both senses, 'turns' or 'comes about', 'turns out' in such and such a way; the participle vrttá means 'turned, elapsed, happened'. The same root underlies proto-Slavonic *verme 'time', from *wert-men. This close semantic connection between turning and eventuating is surely relevant to the image of the goddesses' spindle that spins round as it twists the loose wool into a firm thread. In various languages the word for spindle or spindle-whorl is derived from the same verbal root: Sanskrit vartanā or vartulā, Old Church Slavonic vrĕteno, Middle High German wirtel, Welsh gwerthyd. Perhaps the circling waters of Urð's well were also conceived as an analogue of destiny: Plutarch in his Life of Caesar records that German holy women prophesied by observing river eddies and taking indications from circling currents. 
The spinster goddesses seem also to have been known in Germany. A spinning goddess is represented on a bracteate (a thin plaque of beaten metal) from south-west Germany, and a relief from Trier shows a trio of Mother goddesses, two of them holding distaffs or spindles. German ecclesiastical writers from around the tenth century denounce the people's foolish superstitious belief in the three sisters anciently called 'the Parcae', who determine a man's life at the moment of his birth, and for whom at certain times of year some women lay places at table in anticipation of a visit.

From the Celtic world I can quote the early Irish poem known as Lorica altera, or Breastplate Number Two. It begins:

I call on the seven daughters of the sea

who shape the threads of long life.

Three deaths be taken from me, three lives given to me...

May death not come to me until I am old.

Again a group of goddesses, seven in this case, who 'shape the threads of life', presumably by spinning them.

The Baltic area is of special interest for Indo-European studies, despite the fact that no ancient literature is preserved from it. The art of writing came late, and that is because Christianity came late: to Latvia only in the thirteenth century, to Lithuania only in the fifteenth, and then rather superficially. The names of many pagan deities were remembered and recorded, and a rich tradition of oral folk poetry lived on, perpetuating themes from pre-Christian mythology. The languages themselves are among the most archaic in character of living IndoEuropean tongues.

The goddesses of fate who spin or weave are well attested here. According to a Lithuanian tale reported in 1839 , 'The dieves valditojes [ruling deities] were seven goddesses, the first one spun the lives of men out of a distaff given her by the highest god, the second set up the warp, the third wove in the woof, the fourth told tales to tempt the workers to leave off, for a cessation of labour spoilt the web, the fifth exhorted them to industry, and added length to the life, the sixth cut the threads, the seventh washed the garment and gave it to the most high god, and it became man's winding-sheet.' In another account the 'Spinstress' (verpejja) attaches the thread of each newborn child to a star. (We recall how the golden threads of 
Helgi's life were attached to the mid-point of heaven.) When the person is dying, his thread snaps and the star turns pale and falls as a meteor.

The corresponding Latvian divinities are called Láimas, from the word for fortune. They appear in hundreds of the mythological folk songs, most often in the singular, but occasionally as a trio. The Láima comes to the newborn child's cradle and determines its life. Here is one stanza in which spinning imagery appears:

Láima, Láima for the boy

who is born to the world!

For him Láima twisted the flaxen thread, steeping it in silver.

The motif is widespread also in Slavic folklore. The Russian Rožanicy or Roždenicy, the Czech Sudičky, the Polish Rodzanice, the Slovene Rojenice, the Croat Rodjenice, the Serbian Sudjenice, the Bulgarian Narečnice or Urisnice, are supernatural females who appear at midnight within three days of a birth, mostly in threes, sometimes in a larger group, sometimes in the form of beautiful maidens, sometimes as grandmotherly old women. They spin the child's fate as a golden thread, the eventual breaking or cutting of which will signify his death.

In Albanian lore there are three old women, the Fatit (also called Mir or Ora), who appear on the third day after a birth and fix the child's fate. Phrases are used such as 'to tie off the destiny'; 'predetermine the length of the thread of life'; 'cut off the life'.

Finally we go back in time to the second millennium BC, to the Hittites and their Anatolian kinsmen. Among their numerous deities are the Gulses, or in the Palaic language Gulzannikes, whose name comes from the verbal root guls- 'to write'. The late Professor Oliver Gurney, in his book Some Aspects of Hittite Religion (Oxford 1977, 18), states: 'After much discussion it is now at least clear that these were goddesses of individual destiny, presiding at birth and acting as nurses, also in mythology creatresses of man'. They appear repeatedly in mythical narratives in company with the Mother Goddesses called Hannahannes, and once also with Papaya and Isdustaya, who are, in Gurney's words, 'the Parcae who spin the threads of fate'. The evidence for this is a ritual text for the erection of a new royal palace. When the king enters into it, he commands an eagle to fly towards the sea, and to report on who it sees sitting in field and forest. The eagle reports: 'I have looked. It is Isdustaya and Papaya, the ancient, infernal divinities, who are sitting huddled there.' 'So, what are they doing all the time?' 'She holds a spindle, they hold mirrors 
full of images; and they are spinning the years of the king. And a shortening of his years, even a tally of them, is nowhere to be seen!'

Why is it that spinning is such a pervasive image for the fixing of human destinies? It is a very ancient craft, and it is eminently suited to symbolize the conversion of loose, incoherent possibilities into something definite, something that, like a human life, grows continuously longer but sooner or later is cut off. The process is driven by the rotation of the spindle-whorl, and we have seen that there was an intimate connection in Indo-European speech between turning and eventuating.

Weaving is a related image, strictly appropriate to more multi-dimensional forms of constitution. It is used metaphorically in various connections in IndoEuropean languages. In Greek we find it of devising schemes and stratagems. In Sanskrit and Greek, though not in the earliest literature, and also in one of the Latvian songs, we find it applied to cosmology. In Old Norse we have it of the Valkyries' construction of the battle. The one application of it that may be claimed for Indo-European is to the composition of a poetic or other text. The English word 'text' itself, or Portuguese texto, reflects the use of this metaphor in Latin, as in Plautus' phrase texere sermones.

For the fixing of destinies there is a pair of alternative images that I have already touched on: oral pronouncement and writing. Morta in Livius Andronicus determines the day of death by declaring it in advance: profata est. Fatum is what has been spoken and so fixed. Similarly in Greek, an old poetic word for 'fated' is $\theta \varepsilon \sigma \phi \alpha \tau o v$, literally 'god-spoken'. Like fatum, the word could also be used of oracles. The model is the pronouncement of the king whose word is law.

In cultures that have acquired the art, writing becomes a natural symbol of fixing things for the future. The Hittite and Palaic Fate goddesses, as I mentioned, take their name from the act of writing, and were presumably imagined to establish destinies by writing them down. Tertullian records that on the seventh day after a child's birth the Fata Scribunda would be invoked, figures personifying destinies to be determined in writing. The Nordic goddesses at Urð's well are described as carving [runes] on wooden tablets. In Beowulf we find the phrase 'Fate (Wyrd) did not inscribe for him glory in battle'; the verb used, gescriffan, is a loan from Latin scribere. One of the Latvian songs runs:

Bright, bright burns the fire

in the dark corner.

It is there that Láima is writing the life for the little child. 
But this image cannot go back to Indo-European, as the Indo-Europeans almost certainly had no knowledge of writing. The metaphor developed naturally and independently in the several poetic and mythic traditions.

When the span of life determined by the Fates is completed, one dies. Man is mortal; in the Graeco-Aryan area, as we have seen, human beings can be referred to simply as 'mortals'. What did the Indo-Europeans think about the nature of death and the world of the dead?

They probably made a distinction between natural death that comes in its own time and premature death caused by violence, drowning, or some other manifest external agency. Someone who avoided the latter type and died naturally was said to 'die by his own death': this expression is found in Greek, Latin, Old Persian, Pali, Baluchi, Ossetic, Lithuanian, and several Slavic languages, and it was presumably current at least in the east and central Indo-European territories.

In Latin the two types of death are distinguished as mors and nex. Both words come from Indo-European roots. Many philologists find the nek- root in Greek $\nu \dot{\varepsilon} \kappa \tau \alpha \rho$, which they interpret as 'getting past (premature) death', that is, overcoming the danger of it. They regard it as complementing ' $\alpha \beta \beta \rho \sigma i \alpha$, which would be the appropriate food for avoiding natural death. I am not altogether convinced by this. What is more certain is that ambrosia, as the food of the Greek gods, corresponds to the Indian amrtam, 'the deathless', which is a name applied to the holy cult drink Soma and is at the same time the nourishment of the gods. In formal terms amŕtam corresponds exactly to Greek óp $\mu$ potov, for which ó $\mu \beta p o \sigma$ ' $\alpha$ seems to be a substitute.

From one point of view, death is a kind of sleep. 'Sleep', 'the eternal sleep', 'the sleep of death', etc., is widely used as a metaphor or euphemism for death, at least in Greek, Latin, Sanskrit, Old Norse, and Old English. This is not peculiar to Indo-European languages; it can be found also in the Epic of Gilgamesh and the prophecies of Jeremiah. But of course, if we were perfectly informed about IndoEuropean culture, we would find that it had many things and many ideas in common with non-Indo-European cultures of the time. Its heritage is not the less interesting for that.

Clearly there was more to death than an endless sleep. The dead are generally represented as going somewhere. The 'somewhere' is commonly located below the earth. This is the logical corollary of the fact that in the fourth millennium, which is when the latest phase of undivided Indo-European has to be dated, and in all the lands that come into serious question as the original habitat, disposal of the 
dead was usually by inhumation. The deceased terrestrial returned to his Mother Earth. His tomb was a kind of house - the house of clay, as it is termed in a Vedic hymn. Indeed it was often constructed in the form of a house or chamber that was then covered over by a tumulus.

In mythological thinking the countless individual tombs merged into one place that all the dead go to, under a mountain or under the earth. Greek, Latin, and Vedic poets speak of the lower darkness, the infernae tenebrae; one of the Sanskrit words used in this connection is rájas, which corresponds exactly by etymology to the Greek ع́p\&ßos. The Germanic name for the place is Hel, from which we get the modern English Hell. Norse and Old English poets use the expressions 'he went to Hel', 'you sent my sister to Hel', 'Hel took him'. The word is related to a verb meaning 'conceal' and to an Old Irish word meaning 'cellar', 'underground chamber'.

In some traditions the destination of the dead is known as the house of a certain figure. In Greek it is the house of Hades; I shall come back to the question of what the name Hades means. In Irish it is the house of Donn: Donn perhaps means the Dusky One, from a root related to Latin fuscus. In India it is the house or domain or seat of Yama. Yama, you remember, was the first mortal, the first to accept death. Consequently he became the king of the underworld. In the Mahābhārata warriors are often described as being sent to his abode.

The journey there is spoken of as going the way of no return. This expression in the Indian epics is paralleled in Greek and Latin poetry (you might think of Catullus' illuc unde negant redire quemquam, or Virgil's irremeabilis unda), and also in an Ossetic narrative from the Caucasus. Similarly in a Hittite ritual text, in which the anger of the god Telibinu is sent by spells to underworld, it is observed that 'what goes in does not come out again'. The idea is not distinctively Indo-European, however; a common Sumerian and Akkadian name of the underworld was 'the Land of No Return', and the motif also occurs in the Old Testament.

The boundary between the worlds of the living and the dead was marked by a stream or a body of water, as in the upper world the frontier between peoples is often so marked. The Greeks spoke of crossing the Styx or the Acherusian Lake. A number of Indic texts imply that the dead have to cross a river. One funeral ritual contains the verse, 'On the fearful path that leads to the gates of Yama there is the fearful river Vaitaran̄ī desiring to cross it, I offer the black cow Vaitaran̄i Procopius relates a Germanic myth about how the souls of the dead are ferried over the sea to 'Brittia', which is probably Britain. As late as the nineteenth century, at Morar in the 
west Highlands of Scotland, a Gaelic woman crofter's song was recorded, sung at the New Moon; it referred to going over the black water of the abyss.

In one of the Latvian songs the soul of a dead girl addresses the Mother of the Velanieši, the spirits of the dead, and asks how she is to cross the muddy marsh. The answer comes: 'Lift up your skirts, girl, and cross barefoot.' In another we read:

Be ready, be ready, Mother of the Spirits, here comes the one you are expecting, her skirts black with the muddy water.

More often the crossing is made by means of a bridge or a boat. In Greek myth there is the ferryman Charon to take people across. In Bohemia, Slovakia, and other south and east Slavic lands there is a similar myth of a ferryman, and over the whole Slavic area corpses from the ninth to tenth century onwards were provided with coins in mouth or hand to pay their fare. A Jesuit source of the early seventeenth century records likewise that at Baltic funerals the deceased was provided with two coins in his left hand to pay the ferryman for crossing the river. In Zoroastrian doctrine the soul after death has to cross the Arbiter's Bridge, which is broad for the virtuous but very narrow for the sinful. Similarly an old north English song sung at wakes referred to the bridge of dread, no brader (broader) than a thread'. Saxo Grammaticus, the medieval historian of the Danes, tells how the legendary king Hading was taken by a witch to see the underworld, and how they crossed a bridge over a river of blueblack water, swirling in headlong descent. After the Norse god Baldr was killed, Odin sent his son Hermóðr to Hel to offer a ransom for Baldr's release; Hermóðr rode for nine nights and then arrived at the bridge over the river called Gjoll. This was guarded by a maiden to whom he had to declare his name and family.

'Then Hermóðr rode on till he came to Hel's gates.' Hel's walls, we are told in another passage of the Prose Edda, are extremely high, and her gates strong. The Indian funeral text that I quoted a moment ago mentioned the gates of Yama.

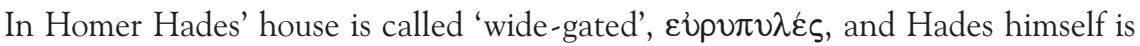
the gate-fastener, $\pi v \lambda \alpha$ ó $\tau$. There are several references in Homer and Hesiod to these gates of Hades. It is natural that a dwelling should have a gate to go in by, and equally natural that this gate should be guarded, to ensure that the right people go in, and in the case of the underworld to ensure that they do not get out again. In Aristophanes' Frogs Dionysus knocks on Hades' door and it is answered by the doorkeeper, who demands to know his name. In other Greek sources this doorkeeper was identified as Aiakos. In the traditional tales of the Ossetes the 
kingdom of the dead is entered by iron gates guarded by a doorkeeper called Aminon. The hero Soslan goes there because he needs to obtain leaves from a certain tree that only grows in the land of the dead. Aminon refuses to open the door for him because he has not died, but he breaks in by force.

As in the upper world many a house is guarded by a dog, who repels those who have no business inside but allows in those who do, so in connection with the abode of the dead we hear in various Indo-European traditions of a dog (or dogs) who belongs to the proprietor and guards the entrance. Classicists are familiar with Cerberus, who according to Hesiod fawns and wags his tail at those who enter but devours any who attempt to leave. Different sources give him three, fifty, or a hundred heads. In the Rigveda the way to the other world is guarded by Yama's two dogs, who seize the dead. Each of them has four eyes, and they are described as spotted, śabála-: this, it has been suggested, was a deformation of a

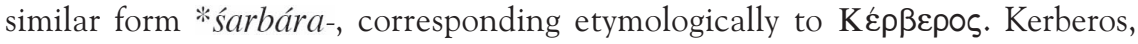
then, would have meant the Spotted One. It is consistent with this theory that $\kappa \dot{\varepsilon}$ $\rho \beta \varepsilon \rho o \varsigma$ is also the name of a type of bird and a kind of frog or toad.

In an Iranian text from the Avesta there is reference to two dogs that guard the bridge over which the dead must go to reach paradise. They assist the virtuous to pass, but not the sinner. In Nordic mythology a dog stands on the road to Hel: Odin meets it as he rides there to investigate the meaning of Baldr's sinister dreams. It has bloody marks on its chest, and it barks fiercely at him as he passes. It is often assumed to be identical with the howling hound Garm, who is bound at the entrance to Gnipa's Cave but will break free in the cosmic cataclysm of Ragnarøk. The Jesuit source on Baltic superstition that I cited earlier records that besides the money for the ferryman, the corpse was provided with a loaf of bread for 'Cerberus', suggesting that in those parts too there lingered the notion of a canine guardian of the underworld. And in Albanian folklore the world of the dead contains a three-headed dog who never sleeps.

The lord of the dead has a house, but he also has wide pasture-lands. Another Homeric epithet of Hades is $\kappa \lambda v \tau \delta$ to $\omega \lambda \circ \varsigma$, famed for his herds of horses. Odysseus in Odyssey 11 sees the dead Achilles and Heracles going about in a meadow. In the Rigveda the land to which Yama, the first to die, has shown us the way is called a pasture, and his Iranian counterpart Yima is huuq $\theta \beta a$-, 'one who has good herds'. A Hittite mortuary ritual for a king includes the prayer

And this meadow, O Sun-god, have rightfully ordained for him! Let none sequester it from him or contest it! 
Let there graze for him in this meadow cattle and sheep, horses and mules!

The Indo-Europeans were pastoralists, and it was pleasant to imagine that their broad pasture-lands would be replicated in the other world.

Dying was seen under another aspect as going to join those who have gone before. Abiit ad plures was a colloquial Latin phrase for 'he has died': 'he has gone to the majority'. In Old Irish death was techt do écaib 'going to the dead'. A number of the Latvian folk songs speak of a deceased person as being taken to the $\mathrm{Ve}<\mathrm{i}$, the spirits of the dead. Hector in the Iliad, after being knocked out by Ajax with a rock, tells Apollo that 'I thought I was about to see the dead and the house of Hades this very day'.

More specifically, dying meant going to join the fathers, the dead of one's own family. The other world, in both Indian and Celtic conception, is the land of the fathers. In a mortuary hymn in the Atharvaveda the dead man is exhorted to 'mount this highest heaven, meeting up with Yama, with the fathers' - 'meeting up with', literally 'finding yourself together with', sam-vidāná. Sam 'together' is from original *sem; as the first element of compounds in Greek this appeared in the reduced form *sm, which developed by regular sound changes into $h a$, as in $\alpha \theta$ póos. The Greek equivalent of sam-vid-would therefore be $\dot{\alpha}-F_{1} \delta-$, and Paul Thieme found here a very plausible etymology of 'Ai ${ }^{\prime} \delta \eta$, as the one who presides over meeting up.

The desire for reunion with the dead finds a different expression in the widespread annual festivals or calendar events at which the souls of the departed, and especially the departed ancestors, are supposed to return to the upper world for one day or a few days at the beginning of winter, or at the middle or end of winter. They are given food, and when their time is up they are told to depart. At Athens the festival in question was the one called Chytroi, which occupied the third day of the Anthesteria at the end of winter. At its conclusion the ghosts were

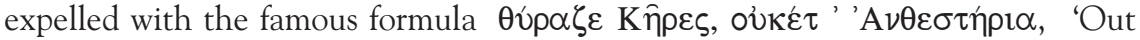
with you, spirits of death, the Anthesteria is over'. The historian Arrian described a feast of the dead among the Bithynians, who were perhaps of Thracian origin. The souls of those who had died abroad were called three times by name and invited to come up from below to share in the sacrificial meal. At Rome there were two relevant festivals, the Parentalia in February and the Lemuria in May. Offerings were put out for the souls of the ancestors, and they were supposed to come and feed while no one watched. Ovid gives the expulsion formula for the Lemuria as 
Manes exite paterni. In India festivals of the dead were held at New Moon or on special occasions such as anniversaries. Pits were dug and food prepared for the souls. The sacrificer prayed, 'Come, you Fathers, you friends of Soma, on your deep old paths. Give us here good property, wealth and unharmed servants.' At the end of the ritual he would say 'Go, you Fathers, you friends of Soma, on your deep old paths'. In Iran the Fravašis, the souls of the faithful, were supposed to revisit the earth for ten days at the end of winter, receive offerings, and dispense prosperity. The Slavic peoples had many festivals of the dead, the main ones being around the winter solstice and in spring. In Latvia and Lithuania they could be at the time of a burial, or after a set period, or in autumn, especially All Souls Day. Meals were left out overnight for the souls, who were invited with prayers to come and partake. They might also be reproached for neglecting the protection of the family's crops and flocks. Afterwards they were turned away or requested to leave the house.

We still have a relic of such old rituals in the modern celebration of Hallowe'en, to which various traditional pagan practices adhere, and the associated Christian feasts of All Saints and All Souls. But there can be little doubt that they go back to Indo-European times and fit organically into a framework of IndoEuropean ideas about death.

Death comes to us all. The Indo-Europeans knew that, and for the GraecoAryans, at least, it was a fact essential to the definition of man. But there is one part of man, they believed, that has a chance of escaping death: his name. What is it, asks a Lithuanian riddle, that does not decay under the earth? The name! In Indian, Greek, Germanic, Celtic, Slavic, Ossetic tales of heroes, we meet again and again the opinion that lasting fame - ideally imperishable fame,

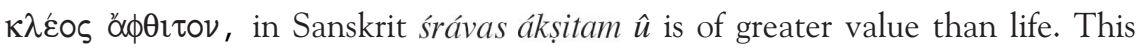
above all is what motivates the warrior to kill and plunder. He desires to be celebrated down the ages.

WEST, M. L. Man, fate and death in Indo-European tradition.

ABSTRACT: This paper deals with Indo-European concepts concerning the human condition: the nature of man, the role of fate in shaping his life, his destiny in death. The evidence is partly drawn from linguistic material, partly from literary. The assumption is that, just as comparison of vocabulary in widely separated languages such as Hittite, Sanskrit and Old Irish makes it possible to reconstruct words of the parent language, so 
comparison of parallel motifs in different traditional literatures may show up inherited ideas and beliefs.

KEYWORDS: Indo-European; man; fate; death. 